\title{
Reduction in Copper Uptake and Inhibition of Prostate Cancer Cell Proliferation by Novel Steroid-based Compounds
}

\author{
FANG XIE ${ }^{1 \#}$ and FANGYU PENG ${ }^{1,2,3}$ \\ ${ }^{1}$ Department of Radiology, ${ }^{2}$ Advanced Imaging Research Center, \\ and ${ }^{3}$ Harold C. Simmons Comprehensive Cancer Center, \\ University of Texas Southwestern Medical Center, Dallas, TX, U.S.A.
}

\begin{abstract}
Background/Aim: Knockdown of human copper transporter 1 has been associated with reduction in copper uptake and suppression of prostate cancer cell proliferation and tumor growth. This study evaluated the effects of steroidbased compounds on copper uptake and proliferation of prostate cancer cells based on their anticancer activity and previous docking analysis of steroid-based copper transporter 1 inhibitors. Materials and Methods: We synthesized several new steroid-based compounds and used ${ }^{64} \mathrm{Cu}$ uptake assay and copper quantification assay with inductively coupled plasma mass spectrometry to study their effects on the cellular copper uptake by prostate cancer cells. Additionally, we used CCK-8 cell proliferation assay to study their effects on the proliferation of prostate cancer cells. Results: Significant reduction in cellular copper uptake was observed in the prostate cancer cells treated with these new steroid-based compounds. Moreover, proliferation of prostate cancer cells was suppressed by treatment with the steroidbased compound $\mathbf{6}$, which had the strongest copper uptake inhibition activity. Conclusion: Reduction in copper uptake and inhibition of cell proliferation were demonstrated in prostate cancer cells treated with the new steroid-based compounds synthesized in this study. Steroid-based copper transporter 1 inhibitors may become novel anticancer drugs for targeted anti-copper therapy of prostate cancer and other copper hypermetabolic cancers.
\end{abstract}

This article is freely accessible online.

\#Current Address: PET Center, Huashan Hospital, Fudan University, Shanghai, P.R. China

Correspondence to: Fangyu Peng, MD, Ph.D., Department of Radiology, University of Texas Southwestern Medical Center, 5323 Harry Hines Blvd, Dallas, TX, U.S.A. E-mail: fangyu.peng@ UTSouthwestern.edu

Key Words: Prostate cancer, steroid-based compounds, anticancer drugs, copper, human copper transporter 1.
Prostate cancer is one of the leading causes of death in men worldwide (1). There are continuous efforts in developing effective drugs for the treatment of patients with castrationresistant prostate cancer lesions in order to improve overall survival of the patients (2-4). Steroids is a class of polycyclic molecules that play an important role in regulating normal physiological processes and pathophysiological responses in combating various diseases (5). Many steroidal derivatives exhibit strong anticancer activity $(6,7)$. Kadioglu et al. have conducted a docking analysis of steroid-based copper transporter 1 inhibitors (8).

Copper is a transitional metal, which fluctuates between oxidized (cupric, $\mathrm{Cu}^{2+}$ ) and reduced states (cuprous, $\mathrm{Cu}^{+}$) in living organisms. Human copper transporter 1 (hCtr1) mediates cellular copper uptake and knock-down of hCtr1 was associated with reduction in cellular copper uptake and suppression of prostate cancer cell proliferation (9). Based on the docking analysis of steroid-based copper transporter 1 inhibitors by Kadioglu et al. (8), we designed and synthesized several new steroid-based compounds and tested their effects on cellular copper uptake and the proliferation of prostate cancer cells for their potential use in the treatment of copper-hypermetabolic prostate cancers.

\section{Materials and Methods}

Reagents and chemical synthesis of steroid derivatives. All chemicals were purchased from Sigma-Aldrich (St. Louis, MO, USA) and used without further purification. Steroid-based compounds were designed according to the docking analysis of steroid-based copper transporter 1 inhibitors by Kadioglu et al. (8) and synthesized using the method shown in Figure $1 .{ }^{1} \mathrm{H},{ }^{13} \mathrm{C}$ NMR spectra were recorded on a Varian $400 \mathrm{MHz}$ spectrometer. Chemical shifts ( $\delta$ values) were reported in ppm and coupling values in Hz. Mass spectrometry (MS) was recorded using the Agilent 6540 UHD Accurate-Mass Quadrupole Time-of-Flight (Q-TOF) LC/MS Systems (Agilent Technologies, Santa Clara, CA, USA).

Copper coordinating ability test. Copper coordinating ability of steroid-based compounds was assessed by measurement of free 

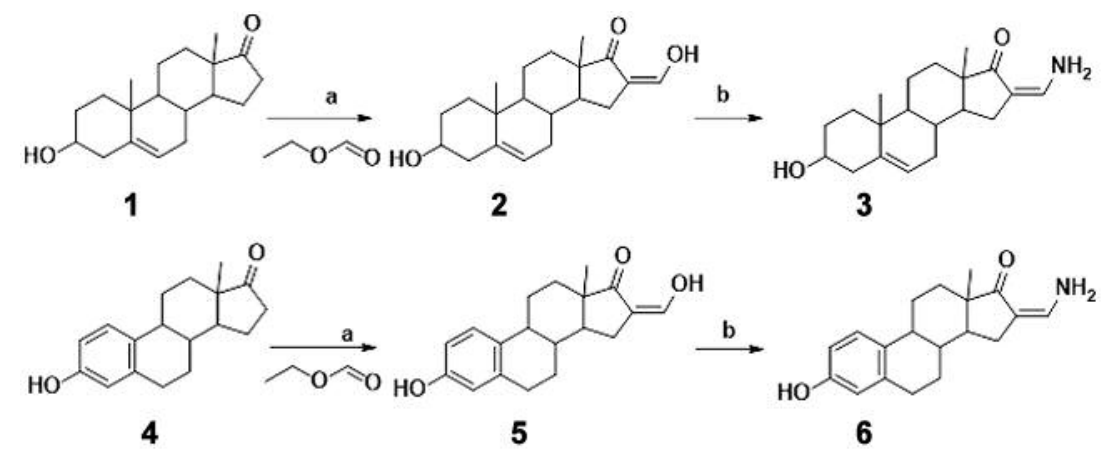

Figure 1. Scheme for synthesis of steroid-based compounds. Reagents and conditions: a) $\mathrm{NaOEt}, \mathrm{CH}_{2} \mathrm{Cl}_{2}$, room temperature, b) reflux, $2 \mathrm{~h} \mathrm{NH} \mathrm{H}_{3} \cdot \mathrm{H}_{2} \mathrm{O}$.

copper ions in the supernatant after incubation of steroid-based compounds with a solution of $\mathrm{CuCl}_{2}$ using a copper assay kit (Sigma-Aldrich). Copper chelators, clioquinol (CQ), and tetrathiomolybdate (TM) were used as control. A mixture of $50 \mu \mathrm{M}$ of steroid-based compounds, CQ, or TM (dissolved in a solution with DMSO) and $50 \mu \mathrm{M}$ of $\mathrm{CuCl}_{2}$ was mixed at a ratio of $1: 1$ or $2: 1$ and incubated for $1 \mathrm{~h}, 12 \mathrm{~h}$, and $24 \mathrm{~h}$, at $37^{\circ} \mathrm{C}$ and $100^{\circ} \mathrm{C}$, respectively. After the incubation, $10 \mu \mathrm{l}$ of the mixture was collected and diluted 1,000 times with water. After centrifugation at 10,000 rpm for $5 \mathrm{~min}$, copper ions in the clear supernatant were measured colorimetrically (359 nm) using a copper assay kit (Sigma-Aldrich). Copper complexes of steroid-based compounds, CQ or TM in the precipitate after centrifugation were analyzed by MS.

Cellular ${ }^{64} \mathrm{Cu}$ uptake assay. The radioactive ${ }^{64} \mathrm{CuCl}_{2}$ was purchased from Washington University (St Louis, MO, USA), which was produced via ${ }^{64} \mathrm{Ni}(\mathrm{p}, \mathrm{n}){ }^{64} \mathrm{Cu}$ on a biomedical cyclotron and supplied in the form of ${ }^{64} \mathrm{CuCl}_{2}$ in $0.1 \mathrm{M} \mathrm{HCl}$ solution. The specific activity of ${ }^{64} \mathrm{Cu}$ was $6.9 \pm 2.5 \mathrm{Ci} / \mu \mathrm{mol}$. The PC-3 prostate cancer cells purchased from ATCC (Manassas, VA, USA) were cultured in 24-well-plates in a density of $1.4 \times 10^{5}$ cells/well overnight. Then, the medium was removed and fresh medium containing 10 and $50 \mu \mathrm{M}$ of steroid-based compounds was added to the wells, with the cells of the control group incubated with cell culture medium only. After $24 \mathrm{~h}$ incubation, the medium was removed and fresh medium containing steroid-based compounds was added, along with $10 \mu \mathrm{l}$ of ${ }^{64} \mathrm{CuCl}_{2}(\sim 9 \mu \mathrm{Ci})$, to the wells and incubated for another $12 \mathrm{~h}$. After washing the cells with phosphate-buffered saline (PBS), $1 \mathrm{ml}$ of $1 \mathrm{M} \mathrm{NaOH}$ was added to wells and incubated in the room temperature for $10 \mathrm{~min}$. Then, the solution was transferred to a tube for $\gamma$ counting of radioactivity using PerkinElmer 2480 Wizard $^{2}$ Automatic $\gamma$ Counter. The protein concentration of each well was determined by using the Pierce ${ }^{\mathrm{TM}}$ BCA protein assay Kit (Thermo scientific, Rockford, IL, USA). The cellular ${ }^{64} \mathrm{Cu}$ uptake was recorded as $\mathrm{cpm} / \mu \mathrm{g}$ protein. A significant decrease in ${ }^{64} \mathrm{Cu}$ activity in the cells incubated with steroid-based compounds compared with the ${ }^{64} \mathrm{Cu}$ activity of cells incubated with medium only was interpreted as the cellular copper uptake reduction effect of the tested steroid-based compounds.

Cellular copper quantification by ICP-MS. Effects of steroid-based compounds on cellular copper uptake were also assessed by quantification of copper ions with inductively coupled plasma mass spectrometry (ICP-MS). PC-3 prostate cancer cells $\left(1 \times 10^{6}\right.$ cells/well) were incubated with $\mathrm{CuCl}_{2}(50 \mu \mathrm{M})$, steroid-based compounds, or steroid-based compounds plus $\mathrm{CuCl}_{2}(50 \mu \mathrm{M})$ for $24 \mathrm{~h}$. At the end of incubation, the medium was removed, and the wells were washed three times with PBS. After digesting cells with trypsin solution (0.3 $\mathrm{ml}$ trypsin/well) in room temperature for $10 \mathrm{~min}$ and washing them with PBS, the cell digests were transferred to a centrifuge tube and centrifuged (900 rpm, $5 \mathrm{~min}$ ). After removal of the supernatant, 0.2 $\mathrm{ml}$ Aquaregia was added to the centrifuge tube. Copper ions of the cellular content in the precipitate were quantified by ICP-MS using a 7700 series ICP-MS instrument (Agilent technologies).

CCK-8 cell proliferation assay. Effect of steroid-based compounds on cell proliferation was assessed with CCK-8 (cell counting kit-8) assay by following the manufacturer's instructions (Dojindo Laboratories, Kumamoto, Japan). Briefly, PC-3 cells on a 96-well microplate $\left(1 \times 10^{4}\right.$ cells/well $)$ were inoculated and cultured overnight. The cells were incubated for 24,48 or $72 \mathrm{~h}$, in fresh cell culture medium containing steroid-based compounds at the noted concentrations $(50$ or $100 \mu \mathrm{M})$. Steroid-based compounds were dissolved in a normal saline solution containing $0.05 \% \mathrm{DMSO}$, and sterilized by filtration with a $0.22 \mu \mathrm{M}$ filter prior to adding onto cell culture wells. At the end of incubation, CCK8 assay solution was added to each well and cell numbers were calculated. The cell numbers at the time of the CCK8 assay were recorded as percentages of the cell numbers initially inoculated. The experiment was conducted in triplicate for each time point and repeated three times. The inhibition concentration $50 \%\left(\mathrm{IC}_{50}\right)$ values were also calculated.

Statistical analysis. The data are expressed as mean \pm SD. Twotailed, unpaired Student's test was used to compare the cellular ${ }^{64} \mathrm{Cu}$ uptake after treatment with steroid derivative compound $\mathbf{6}$ and without treatment. The same test was also used to test the copper ion concentrations in PC-3 cells after treatment with or without steroid derivative compound 6. $p$-Values less than 0.05 were considered statistically significant.

\section{Results}

Chemical synthesis and characterization of steroid-based compounds. Several steroid-based compounds were synthesized using the method shown in Figure 1. Steroid-based compound 
$\mathbf{3}$ and other compounds (compounds $\mathbf{2}$ and $\mathbf{5}$ ) were obtained from the reaction of (+)-Dehydroisoandrosterone (1) or Estrone (4) with ethyl formate, and then with further reaction with $\mathrm{NH}_{4} \mathrm{OH}$ to obtain compounds 3 and $\mathbf{6}$. All the steroid-based compounds obtained were of high yield and purity.

(Z)-3-hydroxy-16-(hydroxymethylene)-10,13-dimethyl-1,2,3, 4,7,8,9,10,11,12,13,14,15,16-tetradecahydro-17H-cyclopenta [a]phenanthren-17-one (steroid-based compound 2). A total of $2.36 \mathrm{~g}(8.19 \mathrm{mmol})$ of (+)-Dehydroandrosterone and ethyl formate $(9.1 \mathrm{~g}, 121 \mathrm{mmol})$ were dissolved in $\mathrm{CH}_{2} \mathrm{Cl}_{2}$ at room temperature. NaOEt $(5.58 \mathrm{~g}, 82.0 \mathrm{mmol})$ was then added into this solution and stirred overnight. Then, the solvent was removed under vacuum. Water was used to dissolve them again and $2 \mathrm{M}$ of $\mathrm{HCl}$ was added to acidify them. A precipitate was formed, which was washed with water followed by water evaporation to obtain the product of compound 2 (2.08 g, 80.2\%).

${ }^{1} \mathrm{H}$ NMR (400 MHz, DMSO) $\delta 10.77(\mathrm{~s}, 1 \mathrm{H}), 7.33(\mathrm{~s}, 1 \mathrm{H})$, $5.26(\mathrm{~s}, 1 \mathrm{H}), 4.61(\mathrm{~s}, 1 \mathrm{H}), 3.21(\mathrm{~s}, 1 \mathrm{H}), 1.05-2.20(\mathrm{~m}, 15 \mathrm{H})$, 0.96-0.99 (m, 5H), $0.74(\mathrm{~s}, 3 \mathrm{H}) .{ }^{13} \mathrm{C}$ NMR (100 MHz, DMSO) $\delta$ 209.06, 150.62, 141.88, 120.50, 113.42, 70.37, 50.28, 49.92, 47.72, 42.63, 37.24, 36.69, 31.81, 31.70, 30.95, $30.67,24.78,20.42,19.57,14.48 . \mathrm{MS}(\mathrm{ESI}+) \mathrm{m} / \mathrm{z}$ : calcd for $\mathrm{C}_{20} \mathrm{H}_{28} \mathrm{O}_{3}[\mathrm{M}+\mathrm{H}]^{+}$317.2, found 317.3. HRMS (EI) $m / z$ : calcd for $\mathrm{C}_{20} \mathrm{H}_{28} \mathrm{O}_{3}[\mathrm{M}+\mathrm{H}]^{+}$317.2072, found 317.2810.

(Z)-16-(aminomethylene)-3-hydroxy-10,13-dimethyl$1,2,3,4,7,8,9,10,11,12,13,14,15,16$-tetradecahydro-17Hcyclopenta[a]phenanthren-17-one (steroid-based compound 3). In $325 \mathrm{mg}$ of steroid derivative compound 2 (1.03 mmol) dissolved in $10 \mathrm{ml}$ of ethanol, $10 \mathrm{ml}$ of ammonium hydroxide was added slowly. After reflux for $30 \mathrm{~min}$, a precipitate begun to form. Then, reflux was performed for another $2 \mathrm{~h}$, followed by recrystallization to obtain product $3(105 \mathrm{mg}, 32.3 \%)$.

${ }^{1} \mathrm{H}$ NMR (400 MHz, DMSO) $\delta 6.38(\mathrm{~s}, 1 \mathrm{H}), 5.27(\mathrm{~s}, 1 \mathrm{H})$, $4.62(\mathrm{~s}, 1 \mathrm{H}), 3.32(\mathrm{~s}, 1 \mathrm{H}), 1.00-2.41(\mathrm{~m}, 16 \mathrm{H}), 0.70-1.00(\mathrm{~m}$, 7H). ${ }^{13} \mathrm{C}$ NMR (100 MHz, DMSO) $\delta$ 206.52, 141.95, $140.99,120.62,105.08,70.40,50.80,50.50,47.18,42.62$, 37.24, 36.73, 32.11, 31.82, 30.94, 25.40, 20.50, 19.56, 14.91 . MS(ESI+) $m / z$ : calcd for $\mathrm{C}_{20} \mathrm{H}_{29} \mathrm{NO}_{2}[\mathrm{M}+\mathrm{H}]^{+} 316.2$, found 316.3. HRMS (EI) $m / z$ : calcd for $\mathrm{C}_{20} \mathrm{H}_{29} \mathrm{NO}_{2}[\mathrm{M}+\mathrm{H}]^{+}$ 316.2232, found 316.2971 .

(Z)-3-hydroxy-16-(hydroxymethylene)-13-methyl$6,7,8,9,11,12,13,14,15,16$-decahydro-17H-cyclopenta[a] phenanthren-17-one (steroid-based compound 5). Steroidbased compound $\mathbf{5}$ was produced using a similar procedure as steroid-based compound 2. Estrone (2.2 g, $8.14 \mathrm{mmol})$, ethyl formate $(9.03 \mathrm{~g}, 122 \mathrm{mmol})$ and NaOEt $(5.54 \mathrm{~g}, 81.4$ mmol) were used to produce compound 5 (2.05 g, $84.4 \%)$. ${ }^{1} \mathrm{H}$ NMR (400 MHz, DMSO) $\delta 10.67(\mathrm{~d}, J=7.3 \mathrm{~Hz}, 1 \mathrm{H})$, $9.01(\mathrm{~s}, 1 \mathrm{H}), 7.38(\mathrm{~d}, J=5.1 \mathrm{~Hz}, 1 \mathrm{H}), 7.03(\mathrm{~d}, J=8.5 \mathrm{~Hz}, 1 \mathrm{H})$,
6.57-6.38 (m, 2H), 2.83-2.61 (m, 2H), 1.72-2.39 (m, 5H), 1.56-1.19 (m, 5H), $0.79(\mathrm{~s}, 2 \mathrm{H}) .{ }^{13} \mathrm{C} \mathrm{NMR}(100 \mathrm{MHz}$, DMSO) $\delta$ 209.05, 155.40, 151.11, 137.52, 130.49, 126.34, 115.38, 113.46, 113.18, 48.84, 48.19, 43.91, 37.91, 31.87, 29.46, 26.72, 26.09, 24.48, 14.82 .

$\mathrm{MS}(\mathrm{ESI}+) \mathrm{m} / \mathrm{z}$ : calcd for $\mathrm{C}_{19} \mathrm{H}_{22} \mathrm{O}_{3}[\mathrm{M}+\mathrm{H}]^{+} 299.2$, found 299.2. HRMS (EI) $m / z$ : calcd for $\mathrm{C}_{20} \mathrm{H}_{28} \mathrm{O}_{3}[\mathrm{M}+\mathrm{H}]^{+}$ 299.1602 , found 299.1775 .

(Z)-16-(aminomethylene)-3-hydroxy-13-methyl-6,7,8,9, $11,12,13,14,15,16$-decahydro-17H-cyclopenta[a] phenanthren-17-one (steroid-based compound 6). Steroidbased compound 6 was obtained in a similar method as steroid-based compound 3. $343 \mathrm{mg}$ of steroid derivative compound 5 (1.15 mmol) was dissolved in ethanol, and 10 $\mathrm{ml}$ of ammonium hydroxide was added. After reflux and recrystallization, the product of compound 6 (125 mg, $36.5 \%)$ was obtained.

${ }^{1} \mathrm{H}$ NMR (400 MHz, DMSO) $\delta 9.12$ (s, 1H), 7.98 (s, 1H), 7.23-6.87 (m, 2H), 6.65-6.53 (m, 2H), 2.93-2.77 (m, 1H), 2.47-2.12 (m, 3H), 2.06-1.80 (m, 2H), 1.65-1.18 (m, 5H), $0.88(\mathrm{~d}, J=14.8 \mathrm{~Hz}, 3 \mathrm{H}) .{ }^{13} \mathrm{C}$ NMR (100 MHz, DMSO) $\delta$ 206.80, 154.87, 141.12, 137.25, 130.47, 125.99, 115.02, $112.81,104.81,49.35,47.33,43.74,39.29,38.87,37.58$, $31.83,29.11,26.55,25.83,24.67,14.85$.

MS(ESI+) $m / z$ : calcd for $\mathrm{C}_{19} \mathrm{H}_{23} \mathrm{NO}_{3}[\mathrm{M}+\mathrm{H}]^{+} 297.2$, found 297.2. HRMS (EI) $\mathrm{m} / \mathrm{z}$ : calcd for $\mathrm{C}_{19} \mathrm{H}_{23} \mathrm{NO}_{3}[\mathrm{M}+$ $\mathrm{H}]^{+} 298.1762$ found 298.2479.

Absence of copper coordinating capability of steroid derivative compounds. Steroid-based compounds were evaluated for their direct copper coordinating ability to determine whether these steroid-based compounds have strong copper binding affinity similar to copper chelators CQ or TM. No significant change in free copper ions was detected in the $\mathrm{CuCl}_{2}$ solution mixed with steroid-based compounds 3 and $\mathbf{6}$, in a 1:1 ratio of ligand to copper concentration (Table I) or a 2:1 ratio of ligand to copper concentration. In contrast, a reduction in free copper was observed in the $\mathrm{CuCl}_{2}$ solution mixed with copper chelator CQ or TM (Table I and Table II). Two CQ removed about one copper ion, while one TM removed one copper in these solutions at all conditions, indicating that CQ and TM chelated copper in a ratio of $2: 1$ and $1: 1$, respectively. This was also shown by MS, with the following peaks of copper chelates with $\mathrm{CQ}\left(\mathrm{CuCQ}_{2}\right.$, calcd for $\mathrm{C}_{18} \mathrm{H}_{10} \mathrm{Cl}_{2} \mathrm{I}_{2} \mathrm{~N}_{2} \mathrm{O}_{2} \mathrm{Cu}[\mathrm{M}+\mathrm{H}]^{+}$672.7507) and TM (CuTM, calcd for $\left.\mathrm{H}_{8} \mathrm{~N}_{2} \mathrm{~S}_{4} \mathrm{MoCu}[\mathrm{M}+\mathrm{H}]^{+} 260.2769\right)$. No peaks of copper complexes were found in the $\mathrm{CuCl}_{2}$ solution mixed with compound $\mathbf{3}$ or $\mathbf{6}$. These findings suggest that the steroid-based compounds synthesized in this study do not have high copper binding affinity of copper chelators such as CQ and TM. 
Table I. Free copper concertation after incubation of $25 \mu M$ of copper and $25 \mu \mathrm{M}$ of steroid-based compounds or copper chelators (ligands:copper $=1: 1$, volume) at $37^{\circ} \mathrm{C}$ for 1,12 , and $24 \mathrm{~h}$. Copper concentration in solution of $\mathrm{CuCl}_{2}$ mixed with compounds $\mathbf{3}$ and $\mathbf{6}$ was similar to the copper concentration in the $\mathrm{CuCl}_{2}$ solution mixed with dimethylsulfoxide (DMSO) of the control. CQ removed about half of copper ions, while TM removed almost all copper ions in the solution.

\begin{tabular}{lccc}
\hline Mixture & $1 \mathrm{~h}$ & $12 \mathrm{~h}$ & $24 \mathrm{~h}$ \\
\hline Compound 3: $\mathrm{CuCl}_{2}$ & $23.8 \pm 0.56$ & $24.1 \pm 0.85$ & $25.0 \pm 0.56$ \\
Compound 6: $\mathrm{CuCl}_{2}$ & $24.1 \pm 0.39$ & $24.0 \pm 1.0$ & $24.2 \pm 1.08$ \\
$\mathrm{CQ}: \mathrm{CuCl}_{2}$ & $13.1 \pm 0.43$ & $12.8 \pm 0.59$ & $12.4 \pm 0.16$ \\
$\mathrm{TM}: \mathrm{CuCl}_{2}$ & $6.17 \pm 0.51$ & $4.60 \pm 0.45$ & $3.25 \pm 0.28$ \\
DMSO : $\mathrm{CuCl}_{2}$ & $24.8 \pm 0.34$ & $24.6 \pm 0.49$ & $25.8 \pm 0.14$ \\
\hline
\end{tabular}

Table II. Free copper concertation after incubation with $25 \mu M$ of copper and $25 \mu M$ of steroid-based compounds or copper chelators (ligands:copper $=2: 1$, volume) at $37^{\circ} \mathrm{C}$ for 1,12 , and $24 \mathrm{~h}$. Copper concentration in solution of $\mathrm{CuCl}_{2}$ mixed with compounds $\mathbf{3}$ and $\mathbf{6}$ was similar to the copper concentration in $\mathrm{CuCl}_{2}$ solution mixed with dimethyl sulfoxide (DMSO) as a control. In contrast, CQ and TM removed most of the free copper from the $\mathrm{CuCl}_{2}$ solutions at a ratio of ligand: copper $=2: 1$ (volume).

\begin{tabular}{lccc}
\hline Mixture & $1 \mathrm{~h}$ & $12 \mathrm{~h}$ & $24 \mathrm{~h}$ \\
\hline Compound 3: $\mathrm{CuCl}_{2}$ & $15.5 \pm 1.20$ & $16.3 \pm 0.58$ & $17.5 \pm 0.67$ \\
Compound 6: $\mathrm{CuCl}_{2}$ & $16.1 \pm 0.49$ & $14.9 \pm 0.59$ & $16.0 \pm 0.64$ \\
$\mathrm{CQ}: \mathrm{CuCl}_{2}$ & $1.53 \pm 0.51$ & $1.81 \pm 1.98$ & $0.56 \pm 0.28$ \\
$\mathrm{TM}: \mathrm{CuCl}_{2}$ & $4.69 \pm 0.51$ & $4.60 \pm 0.34$ & $4.78 \pm 1.15$ \\
DMSO : $\mathrm{CuCl}_{2}$ & $16.6 \pm 0.21$ & $16.3 \pm 0.39$ & $17.9 \pm 0.61$ \\
\hline
\end{tabular}

Reduction in copper uptake by PC-3 cells treated with steroid-based compounds. Significant reduction in ${ }^{64} \mathrm{Cu}$ uptake was detected in the cells treated with $50 \mu \mathrm{M}$ of steroid-based compounds for $24 \mathrm{~h}$ in vitro by the cellular ${ }^{64} \mathrm{Cu}$ uptake assay (Figure 2A). Among the steroid-based compounds tested (compound $2, \mathbf{3}, \mathbf{5}$, and $\mathbf{6}$ ), compound $\mathbf{6}$ showed the strongest inhibitory effect on cellular ${ }^{64} \mathrm{Cu}$ uptake by PC-3 prostate cancer cells. Cellular ${ }^{64} \mathrm{Cu}$ uptake was decreased $50 \%$ after treatment of cells with $10 \mu \mathrm{M}$ of compound 6 and cellular ${ }^{64} \mathrm{Cu}$ uptake was decreased $80 \%$ when the cells were treated with $50 \mu \mathrm{M}$ of compound $\mathbf{6}$. Reduction in cellular copper uptake after treatment with steroid-based compounds was further confirmed by copper quantification using ICP-MS. Copper levels increased from $4.03 \pm 0.33$ to $7.55 \pm 0.80 \mu \mathrm{g} / \mathrm{mg}$ protein after $24 \mathrm{~h}$ incubation of cells with $50 \mu \mathrm{M}$ of $\mathrm{CuCl}_{2}$. Compared with the copper level of $7.55 \pm 0.80 \mu \mathrm{g} / \mathrm{mg}$ protein in the cells incubated with $\mathrm{CuCl}_{2}$, cellular copper level was significantly decreased to $6.21 \pm 0.42$ and $5.61 \pm 1.36 \mu \mathrm{g} / \mathrm{mg}$ protein $(p<0.05)$ after $24 \mathrm{~h}$ incubation of cancer cells with $50 \mu \mathrm{M}$ of compound 6 plus
$\mathrm{CuCl}_{2}$ or $100 \mu \mathrm{M}$ of compound 6 plus $\mathrm{CuCl}_{2}$ (Figure 2B). No significant difference in copper concentration was found between the PC-3 cells treated with $50 \mu \mathrm{M}$ of compound $\mathbf{6}$, $100 \mu \mathrm{M}$ of compound $\mathbf{6}$, or cell culture medium, individually (Figure 2B).

Suppression of prostate cancer cell proliferation by steroidbased compounds. Suppressed proliferation of PC-3 cells was observed following incubation of cells with steroid-based compound 6 for $24,48,72 \mathrm{~h}$ (Figure 3). The $\mathrm{IC}_{50}$ value of compound 6 was calculated at $104.27 \mu \mathrm{M}$, compared with the $\mathrm{IC}_{50}$ value of $122.06 \mu \mathrm{M}$ for compound $2,179.63 \mu \mathrm{M}$ for compound 3, $>200 \mu \mathrm{M}$ for $\mathrm{TM}$ as a control.

\section{Discussion}

Copper is required for cell proliferation and plays a role in uncontrolled cancer cell proliferation $(10,11)$. Expression of $\mathrm{hCtr} 1$ was elevated in cancer cells to meet the increased demand of copper for the rapid growth of cancer cells (12). RNAi-mediated knockdown of hCtr1 was associated with reduction in ${ }^{64} \mathrm{Cu}$ uptake by positron emission tomography/computed tomography imaging and growth inhibition of human prostate cancer xenograft tumors in mice (9). In 2015, Kadioglu et al. reported a docking analysis of steroid-based copper transporter 1 inhibitors (8). In this study, we designed and synthesized several new steroidbased compounds using cimetidine as the lead compound. Significant reduction in copper uptake by PC-3 prostate cancer cells treated with steroid-based compounds was demonstrated by the cellular ${ }^{64} \mathrm{Cu}$ uptake assay (Figure 2A) and copper quantification by ICP-MS (Figure 2B). Steroidbased compound $\mathbf{6}$ showed the strongest reduction effect on cellular copper uptake among the new steroid-based compounds synthesized in this study. In contrast to the copper chelators CQ and TM, the steroid-based compounds synthesized in this study (compounds $\mathbf{3}$ and $\mathbf{6}$ ) did not show high copper binding affinity as measured by the copper coordinating assay (Table I and Table II).

We also further tested the effects of compound $\mathbf{6}$ on the proliferation of prostate cancer cells. As expected, proliferation of PC-3 prostate cancer cells was suppressed after treatment with compound 6 (Figure 3). Copper chelators such as TM have been clinically tested as anticopper cancer therapy; however, the clinical application of anti-copper cancer therapy with TM was hampered by the side effects of global copper depletion, such as bone marrow suppression manifested as anemia (13). The $\mathrm{IC}_{50}$ value of steroid-based compound $\mathbf{6}$ was calculated at $104.27 \mu \mathrm{M}$ compared with the $\mathrm{IC}_{50}$ value $>200 \mu \mathrm{M}$ of $\mathrm{TM}$. The findings of this study support further investigation of steroid-based compounds as potential hCtr1 inhibitors, compatible with the previous docking analysis of steroid-based copper transporter 
A

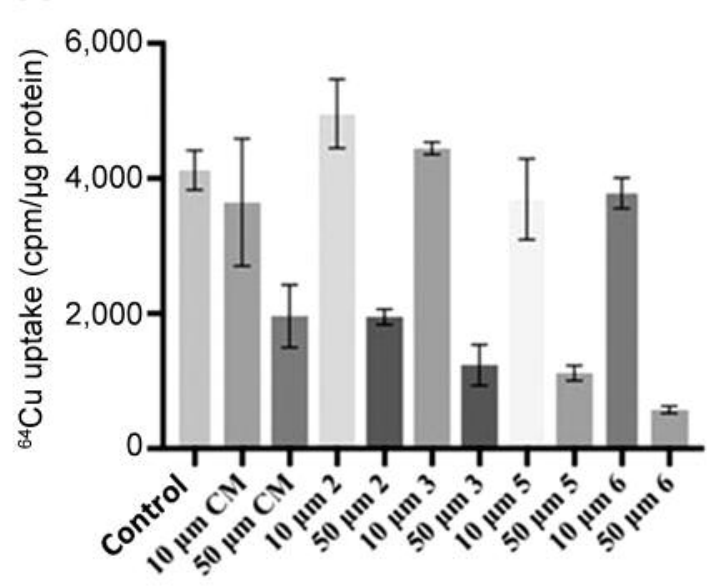

B

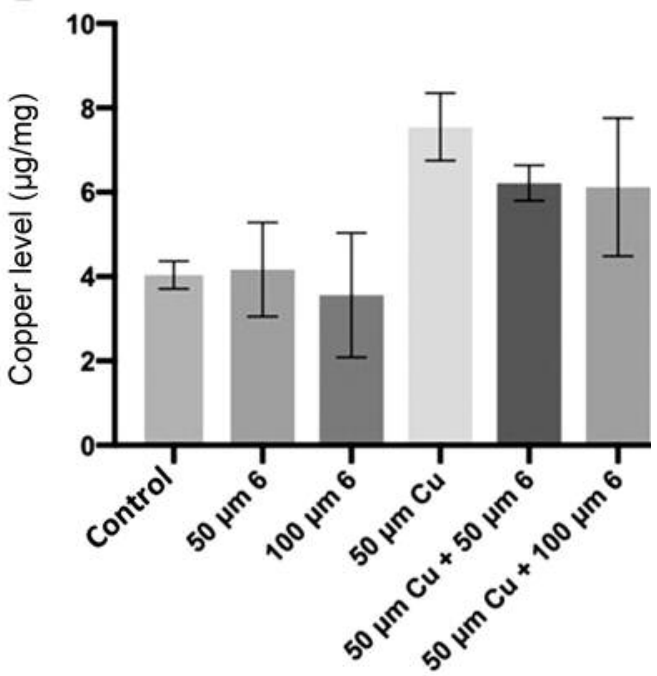

Figure 2. Reduction in copper uptake in cells treated with steroid-based compounds. A. Decreased ${ }^{64} \mathrm{Cu}$ uptake was detected in PC-3 cells treated with $50 \mu \mathrm{M}$ of steroid-based compounds $2, \mathbf{3 , 5}$, or $\mathbf{6}$ as measured by the cellular ${ }^{64} \mathrm{Cu}$ uptake assay. B. Reduced copper ions in PC-3 cells treated with compound 6 and $\mathrm{CuCl}_{2}$ by ICP-MS. Concentration of copper ions in PC-3 cells treated with $50 \mu \mathrm{M}$ of CuCl $\mathrm{Pl}_{2}$ plus 50 or $100 \mu \mathrm{M}$ of compound 6 was significantly lower than the copper concentration of $\mathrm{PC}-3$ cells treated with $50 \mu \mathrm{M}$ of $\mathrm{CuCl}_{2}(p<0.05)$, indicating a suppression of cellular copper uptake after treatment with compound 6. CM: Culture medium.

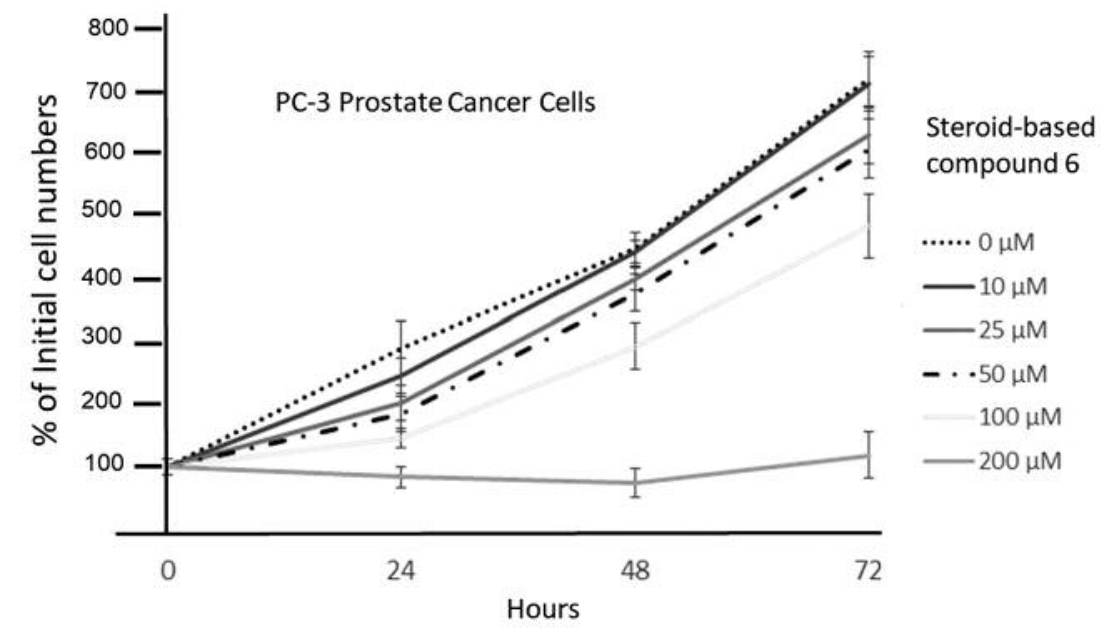

Figure 3. Proliferation of PC-3 cancer cells was inhibited after treatment with various concentrations of compound $\mathbf{6}$, in a time- and concentrationdependent manner.

1 inhibitors (8). Additional docking analysis of steroid-based compounds synthesized in this study, as well as binding affinity assay using hCtr1 molecules will be significant for determining whether steroid-based compounds are indeed hCtr1 inhibitors. Successful development of hCtr1 inhibitors will be highly significant for targeted anti-copper therapy of prostate cancer and other copper hypermetabolic cancers.

\section{Conclusion}

Significant reduction in copper uptake was demonstrated by prostate cancer cells treated with the newly synthesized steroid-based compounds. Proliferation of prostate cancer cells was inhibited after treatment with steroid-based compound 6 that exhibited the strongest inhibitory activity on cellular 
copper uptake of prostate cancer cells. The findings of this study provided strong evidence to support further investigation of steroid-based compounds as anti-prostate cancer agents targeting copper's role in cell proliferation. The steroid-based compounds hold potential for treatment of prostate cancer and other cancers that required copper for uncontrolled cell proliferation and tumor growth.

\section{Conflicts of Interest}

The Authors declare that there are no conflicts of interest concerning this article.

\section{Authors' Contributions}

Hypothesis and conceptual design of this study: FP; Synthesis and characterization of chemical compounds, and execution of experiments: FX; Data analysis and manuscript writing: FX and FP.

\section{Acknowledgements}

This research project was partially supported by the National Institutes of Health (1R21NS074394-01A1 and 1R21AG04795301). The Authors thank Xiankai Sun for the use of the ICP-MS instrument and also Aditi Mulgaonkar for her assistance.

\section{References}

1 Siegel RL, Miller KD and Jemal A: Cancer statistics, 2017. CA Cancer J Clin 67(1): 7-30, 2017. PMID: 28055103. DOI: $10.3322 /$ caac. 21387

2 Nass SJ, Rothenberg ML, Pentz R, Hricak H, Abernethy A, Anderson K, Gee AW, Harvey RD, Piantadosi S, Bertagnolli MM, Schrag D and Schilsky RL: Accelerating anticancer drug development - opportunities and trade-offs. Nat Rev Clin Oncol 15(12): 777-786, 2018. PMID: 30275514. DOI: 10.1038/s41571$018-0102-3$

3 Xie F and Peng F: Anti-prostate cancer activity of 8hydroxyquinoline-2-carboxaldehyde-thiosemicarbazide copper complexes by fluorescent microscopic imaging. J Fluoresc 27(6): 1937-1941, 2017. PMID: 28653241. DOI: 10.1007/s10895-0172133-Z

4 Xie F, Cai $\mathrm{H}$ and Peng F: Anti-prostate cancer activity of 8hydroxyquinoline-2-carboxaldehyde-thiosemicarbazide copper complexes in vivo by bioluminescence imaging. J Biol Inorg Chem 23(6): 949-956, 2018. PMID: 30006867. DOI: 10.1007/s00775018-1596-y
5 Miller WL and Auchus RJ: The molecular biology, biochemistry, and physiology of human steroidogenesis and its disorders. Endocr Rev 32(1): 81-151, 2011. PMID: 21051590. DOI: 10.1210/er.2010-0013

6 Gupta A, Kumar BS and Negi AS: Current status on development of steroids as anticancer agents. J Steroid Biochem Mol Biol 137: 242-270, 2013. PMID: 23727548. DOI: 10.1016/j.jsbmb.2013.05.011

7 Shi YK, Wang B, Shi XL, Zhao YD, Yu B and Liu HM: Synthesis and biological evaluation of new steroidal pyridines as potential anti-prostate cancer agents. Eur J Med Chem 145: 11-22, 2018. PMID: 29310026. DOI: 10.1016/j.ejmech.2017.12.094

8 Kadioglu O, Serly J, Seo EJ, Vincze I, Somlai C, Saeed ME, Molnár J and Efferth T: Molecular docking analysis of steroidbased copper transporter 1 inhibitors. Anticancer Res 35(12): 6505-6508, 2015. PMID: 26637863.

9 Cai H, Wu JS, Muzik O, Hsieh JT, Lee RJ and Peng F: Reduced $64 \mathrm{Cu}$ uptake and tumor growth inhibition by knockdown of human copper transporter 1 in xenograft mouse model of prostate cancer. J Nucl Med 55(4): 622-628, 2014. PMID: 24639459. DOI: $10.2967 /$ jnumed.113.126979

10 Brady DC, Crowe MS, Turski ML, Hobbs GA, Yao X, Chaikuad A, Knapp S, Xiao K, Campbell SL, Thiele DJ and Counter CM: Copper is required for oncogenic BRAF signalling and tumorigenesis. Nature 509(7501): 492-496, 2014. PMID: 24717435. DOI: $10.1038 /$ nature 13180

11 Grubman A and White AR: Copper as a key regulator of cell signalling pathways. Expert Rev Mol Med 16: e11, 2014. PMID: 24849048. DOI: $10.1017 /$ erm.2014.11

12 Denoyer D, Clatworthy SA, Masaldan S, Meggyesy PM and Cater MA: Heterogeneous copper concentrations in cancerous human prostate tissues. Prostate 75(14): 1510-1517, 2015. PMID: 26012532. DOI: $10.1002 /$ pros.23022

13 Brewer GJ, Dick RD, Grover DK, LeClaire V, Tseng M, Wicha M, Pienta K, Redman BG, Jahan T, Sondak VK, Strawderman M, LeCarpentier G and Merajver SD: Treatment of metastatic cancer with tetrathiomolybdate, an anticopper, antiangiogenic agent: Phase I study. Clin Cancer Res 6(1): 1-10, 2000. PMID: 10656425.
Received October 5, 2021

Revised October 26, 2021

Accepted October 29, 2021 